\title{
SPAD GREENNESS TO ESTIMATE GENOTYPIC VARIATION IN FLAG LEAF CHLOROPHYLL IN SPRING WHEAT UNDER MEDITERRANEAN CONDITIONS
}

\author{
Celaleddin BARUTCULAR ${ }^{I^{*}}$, Irem TOPTAS ${ }^{l}$, Hatice TURKTEN ${ }^{2}$, Mehmet YILDIRIM $^{3}$, Mujde KOC $^{l}$ \\ ${ }^{1}$ Cukurova University, Faculty of Agriculture, Department of Field Crops, Adana, TURKEY \\ ${ }^{2}$ Ondokuz Mayls University, Faculty of Agriculture, Department of Agricultural Economics, Samsun, \\ TURKEY \\ ${ }^{3}$ Dicle University, Faculty of Agriculture, Department of Field Crops, Diyarbakır, TURKEY \\ Corresponding author: cebar@cu.edu.tr
}

Received: 01.07.2014

\begin{abstract}
Leaf chlorophyll (Chl) is emphasized as an indicator for photosynthesis in wheat (Triticum aestivum L.). SPAD greenness meters are used to predict extractable $\mathrm{Chl}$, but few studies have evaluated relationships between flag leaf greenness and $\mathrm{Chl}$ among wheat genotypes. Sixteen spring wheat genotypes with similar development patterns were studied in eight environments ( 2 years, 2 irrigation treatments and 2 sowing times) to investigate the precision of the SPAD-502 meter to predict Chl content/concentration. Relationships of Chl with SPAD greenness generally best fit linear and quadratic models. Relationships of SPAD greenness with Chl concentration were weak and inconsistent. Strongest associations were observed with $\mathrm{Chl}_{\mathrm{a}}$ content (highest $\boldsymbol{R}^{2}$ $=0.71$ under late sowing), whereas associations with $\mathrm{Chl}_{\mathrm{b}}$ content were weak (highest $\left.R^{2}=0.46\right)$ or insignificant. Relationships between SPAD greenness and total Chl content ranged from low $\left(R^{2}=0.24, p=\right.$ $0.054)$ to moderate $\left(R^{2}=0.64, p<0.001\right)$ under rainfed conventional-sowing and late-sowing conditions in the second year, respectively. SPAD greenness can be used to diagnose spring wheat genotypes differing in flag leaf $\mathrm{Chl}_{\mathrm{a}}$ and total $\mathrm{Chl}$ content under warm Mediterranean conditions, but may not always applicable in cooler Mediterranean conditions, where genetic variability, especially in $\mathrm{Chl}_{b}$, was not expressed adequately.
\end{abstract}

Key words: Chlorophyll meter, Chlorophyll content, Chlorophyll concentration, Flag leaf, Spring wheat, drought

\section{INTRODUCTION}

Chlorophyll $a$ and chlorophyll $b$ are essential pigments of the plant photosystems (Richardson et al., 2002). In wheat (Triticum aestivum L.), chlorophyll content is positively correlated with photosynthetic rate (Evans, 1983). Leaf chlorophyll (measured by extraction and quantification of pigment content or with optical chlorophyll meters) is increasingly emphasized as an indicator for photosynthetic capacity and its stability during senescence (the 'stay green' phenotype) under both stress and non-stress conditions, and therefore for yield in wheat (Reynolds et al., 1994; Araus et al., 2008; Parry et al., 2011; Xiao et al., 2012).

Traditional extraction-based methods of measuring chlorophyll $a\left(\mathrm{Chl}_{\mathrm{a}}\right)$, chlorophyll $b\left(\mathrm{Ch}_{\mathrm{b}}\right)$ and total chlorophyll $\left(\mathrm{Chl}_{\mathrm{a}+\mathrm{b}}\right)$ in leaves are destructive and time consuming (Richardson et al., 2002). Therefore, handheld optical chlorophyll meters, such as SPAD (soil plant analysis development) meters, based on the absorbance, reflectance and/or transmittance of radiation by the intact leaf, have been developed. SPAD chlorophyll meters determine the relative amount of total leaf chlorophyll in intact leaves and produce values that express relative chlorophyll content (SPAD greenness), but not of absolute chlorophyll amount per unit area (content) nor per mass (concentration) of leaf tissue. Taking SPAD readings is easy, rapid and non-destructive; therefore, use of SPAD greenness meters has increased dramatically in recent years.

SPAD readings have been used to predict chlorophyll content in a large number of crop species, such as corn (Markwell et al., 1995), sorghum and pigeonpea (Yamamoto et al., 2002), soybean (Fritschi and Ray, 2007), wheat and potato (Uddling et al., 2007) and basil (Ruiz-Espinoza et al., 2010). A number of studies, restricted to one or a small number of genotypes, have reported a curvilinear relationship between extractable chlorophyll and SPAD values in wheat (Monje and Bugbee, 1992; Castelli et al., 1996; Richardson et al., 2002; Uddling et al., 2007). However, Castelli et al. 
(1996) reported that monocots (wheat and maize) and dicots (tobacco and soybean) show distinct patterns in terms of the relationship between non-destructive readings and analytical results obtained by solvent extraction.

Indeed, the SPAD value depends not only on extractable chlorophyll concentrations, but also on other aspects of leaf optics, which may be affected by a variety of environmental and biological factors (Palta, 1990; Hoel and Solhaug, 1998; Markwell et al., 1995; Martínez and Guiamet, 2004). The non-homogeneous distribution of chlorophyll molecules within the leaf and/or differential scattering and reflection of radiation can alter the relationship between extractable chlorophyll and SPAD greenness (Monje and Bugbee, 1992; Markwell et al., 1995; Uddling et al., 2007).

The lack of a consistent relationship between chlorophyll estimated with an extraction method and by the greenness meter for different genotypes may limit the potential use of SPAD as a complementary selection trait. The relationship between chlorophyll content/ concentration determined with an extraction method and by a SPAD chlorophyll meter have been verified depending on sowing time and irrigation threatment among wheat genotypes

In synthetic hexaploid wheat the variation in SPAD greenness is not completely explained by changes in chlorophyll concentration (Del Blanco et al., 2000). Thus it is necessary to verify the relationship between extractable chlorophyll and SPAD greenness in different genotypes under different environmental conditions to enable breeders to select more easily for genotypes differing in chlorophyll content or concentration, when the source capacity is to be improved. This objective is particularly important if not only chlorophyll content/concentration, but also chlorophyll components $\left(\mathrm{Chl}_{\mathrm{a}}, \mathrm{Chl}_{\mathrm{b}}, \mathrm{Chl}_{\mathrm{a}+\mathrm{b}}\right.$ and ratio of $\mathrm{Chl}_{\mathrm{a}}$ to $\left.\mathrm{Chl}_{\mathrm{b}}\left[\mathrm{Chl}_{\mathrm{a} / \mathrm{b}}\right]\right)$, are to be considered.

The objective of this study was to examine if SPAD greenness could be used as a rapid screening method to predict genotypic variation in wheat for extractable leaf chlorophyll content/concentration $\left(\mathrm{Chl}_{\mathrm{a}}, \mathrm{Chl}_{\mathrm{b}}\right.$ and $\left.\mathrm{Chl}_{\mathrm{a}+\mathrm{b}}\right)$ and $\mathrm{Chl}_{\mathrm{a} / \mathrm{b}}$, and to assess the stability of these relationships in different environments. To eliminate possible phenotypic differences in chlorophyll content, genotypes with similar or known development patterns were used.

\section{MATERIALS AND METHODS}

\section{Plant materials and cultural practices}

Field experiments were conducted during the 2011/2012 and 2012/2013 growing seasons at the experimental field of the Faculty of Agriculture, University of Cukurova, Balcall, Adana $\left(37^{\circ} 00^{\prime} \mathrm{N}, 35^{\circ} 21^{\prime}\right.$ E, $29 \mathrm{~m}$ above sea level), Turkey. The soil type is a fine loamy, montmorillonitic typic xerofluvent, low in organic matter and slightly alkaline (pH 7.1-7.6).

Sixteen unrelated spring bread wheat (Triticum aestivum) genotypes with a similar developmental pattern selected for diversity in leaf traits were used. The widely adapted genotypes comprised commercial cultivars from Turkey (Adana-99, Balattila, Cemre, Cumakalesi, Genç99, Karacadağ-98, Meta-2002 and Özkan), ICARDA (Cham-6 and Siete Cerros), Israel (Dariel and Galil), Italy (Colfiorito), Spain (Mané-Nick) and Pakistan (Inqilab-91 and V-3010).

In each growing season (2011/2012 and 2012/2013) in addition to conventional (optimal) sowing time (CS) and late sowing (LS) times were used to expose the cultivars to lower and higher temperatures. Each replication of the sowing times (main plots) was nested on the same field with two irrigation treatments (rainfed, RF; and irrigated, IR) as subplots and genotypes as mini-plots in a split-split plot randomised design of four replications.

Except for sowing time and irrigation treatment, the growing conditions were maintained as similar as possible through fertilization and pest control. The first-year sowings were on 25 November 2011 and 8 March 2012, and the second-year sowings were on 29 November 2012 and 8 March 2013, for CS and LS, respectively. Phosphorus $\left(40 \mathrm{~kg} \mathrm{ha}^{-1} \mathrm{P}_{2} \mathrm{O}_{5}\right.$ ) was applied before sowing in the form of triple super phosphate. Nitrogen was applied as ammonium nitrate in three split doses $(40+80$ $+40 \mathrm{~kg} \mathrm{~N} \mathrm{ha}^{-1}$ ) at Zadok's (Zadoks et al., 1974) growth stages (ZGS) 00, 20 and 30. The sowing density was 450 viable seeds $\mathrm{m}^{-2}$. Plots consisted of 8 rows, each of which was $6.0 \mathrm{~m}$ long with a row spacing of $0.15 \mathrm{~m}$.

The irrigation applications were initiated on 6 April 2012 with CS and 12 May 2012 with LS in the first year. The respective dates in the second year were 19 March 2013 and 1 May 2013. Water supplies between irrigated and rainfed conditions in first year were similar. Firstyear water supply (rainfall + irrigation) until sampling time was 671 and $682 \mathrm{~mm}$ for RF and IR, repsectively, and 255 and $255 \mathrm{~mm}$ in CS and LS, respectively. The respective water supply in the second year was 459,501 , 169 and $199 \mathrm{~mm}$.

\section{Measurement of SPAD greenness and extractable leaf chlorophyll}

SPAD greenness and extractable leaf chlorophyll were measured on flag leaves. Sampling was performed before the onset of leaf senescence at the end of anthesis (2012 CS), at the beginning of anthesis (2012 LS and 2013 CS), and of heading (2013 LS) 1 week (in LS) or 2 weeks (in CS) after initiation of the irrigation regimes. Five healthy flag leaf blades were sampled at random from the central rows of each plot and transported in cool isolation boxes to the laboratory. The leaves were kept in a refrigerator before processing. Samples from one replication were processed within approximately $2 \mathrm{~h}$ from collection in the field.

In the laboratory, at first SPAD chlorophyll was measured on sampled fresh leaves using a hand-held SPAD-502 Chlorophyll Meter (Minolta Camera Co., Osaka, Japan), which generates a value predictive of chlorophyll concentration (Minolta Camera Co. 1989). 
The SPAD-502 meter measures transmittance at 650 $\mathrm{nm}$ (red light is strongly absorbed by chlorophyll) and 940 $\mathrm{nm}$ (near-infrared light is a 'reference wavelength' that is used to adjust for differences in leaf structure) of radiation through the leaf, and calculates a relative SPAD meter value that is termed SPAD greenness. The average of three readings from the center of each leaf blade was used as a SPAD greenness score per leaf $(5 \times 3$ readings per plot). The midpoint of the leaf is the best position in winter wheat plants on which to take chlorophyll meter readings (Hoel and Solhaug, 1998). The adaxial side of the leaves was always placed toward the emitting window of the instrument and major veins were avoided.

Following each SPAD reading, the amount of chlorophylls $\left(\mathrm{Chl}_{\mathrm{a}}\right.$ and $\left.\mathrm{Chl}_{\mathrm{b}}\right)$ was determined in two leaf disks of $8 \mathrm{~mm}$ diameter taken from an identical position of the same leaves. After the disks were weighed, pigments were thoroughly extracted in $80 \%$ (v/v) acetone using a glass mortar, and the homogenate was then filtered. Absorbance was measured at the relevant wavelength with a spectrophotometer (Shimadzu, UV-1208, Kyoto, Japan). Chlorophyll content/concentration was calculated on a leaf area/fresh weight basis using the equations of Porra et al. (1989). These equations are an improvement over the widely used equations of Arnon (1949).

\section{Data analysis}

Although irrigation was initiated a short time prior to sampling for SPAD greenness and extractable leaf chlorophyll measurement, and differences in water supply between irrigation treatments were small, analysis of variance (ANOVA) of the traits was carried out first on the basis of the experimental design used (a randomized split-split plot) with sowing date as the main factor, irrigation as a sub-plot, and genotype as a mini-plot with four replications. Subsequently, analyses of variance for each growing condition were performed separately to obtain a clearer picture for flag leaf traits of the genotypes. Least significant difference (LSD) values were calculated at the 0.05 level of probability. A regression was used when appropriate. The SPSS (1999) package was used for all analyses.

\section{RESULTS AND DISCUSSION}

\section{Development of genotypes}

As a result of the small pre-anthesis differences in water supply between the irrigation treatments, no effect of irrigation (and its interaction with genotype) on development of the wheat genotypes was observed (data not shown). Under CS, anthesis (ZGS 60, averaged over genotypes) occurred 138 and 123 days after sowing in 2012 and 2013, respectively. The respective values under LS were 69 and 66 days. When the relative thermal duration (determined as cumulative growing degree-days from sowing to sampling date, base temperature $0{ }^{\circ} \mathrm{C}$ ) was considered, acceleration of anthesis by LS was in a narrow range from 1376 to $1149{ }^{\circ} \mathrm{C}$ days $(16 \%)$ and from 1439 to $1151^{\circ} \mathrm{C}$ days $(20 \%)$ in 2012 and 2013 , respectively. These results indicated the overwhelming effect of growing temperature on development.

Despite the obvious genotypic trends, the development of most genotypes was very similar. Only the local Turkish cultivar Cumakalesi was consistently the latest to flower and Karacadağ-98 tended to be the earliest to anthesis. Development of the remaining genotypes was tightly clustered in the first year, especially with LS. Genotypic differences in the second year (particularly with LS) were more pronounced, but ZGS values changed only within a narrow range of development such as from heading (ZGS 57) to completion of anthesis (ZGS 67).

It is well known that the growth stage also affects chlorophyll pigments, and therefore SPAD readings (Lopes and Reynolds, 2012). The similar (or known) developmental pattern of each genotype in the present study allowed valid comparison of SPAD greenness and extractable chlorophylls among the genotypes.

\section{Flag leaf SPAD greenness and extractable chlorophylls}

The results of ANOVA over years showed consistently highly significant genotypic effects, whereas other effects were inconsistent (sowing time), negligible (irrigation) or extremely variable (interactions) (data not shown). To obtain a clearer picture, the maximum, minimum and mean values for flag leaf traits of each genotype under each conditions (two sowing times and two irrigation treatments in the 2 study years) and LSD values calculated based on the results of ANOVA for individual conditions (hereafter termed 'environments') are presented separately in Table 1. With a few exceptions for chlorophyll concentration and content under certain conditions, genotypic differences for SPAD greenness and extractable chlorophylls were significant (Table 1) and more or less consistent (data not shown). Here emphasis is placed more on the extent of genotypic changes rather than on genotypic differences per se.

Senescing leaves in wheat suffer the loss of chlorophylls, especially $\mathrm{Chl}_{\mathrm{a}}$ (Reynolds et al., 2000; Zhang et al., 2006). Thus the leaf age affects chlorophyll pigments, and therefore SPAD readings (Lopes and Reynolds, 2012). Except only one cultivar, the similar developmental pattern and similar leaf age of the genotypes in the present study allowed valid comparison of SPAD greenness and extractable chlorophylls among the genotypes.

\section{SPAD greenness}

Although highly significant differences among genotypes were observed in all environments, SPAD greenness values changed within rather narrow ranges (mean change 23\%) (Table 1). The highest change of $40 \%$ occurred from 38.5 to 53.9 in the first year in the LS rainfed environment (2012 LSRF), and the lowest changes (17\%) from 44.6 to 52.0 and 44.5 to 52.2 were observed in 2013 in the CS rainfed and CS irrigated environments (2013 CSRF and CSIR), respectively. Changes in the other environments were more or less similar. 
Table 1. Maximum, minimum and mean flag leaf SPAD greenness, chlorophyll $a\left(\mathrm{Chl}_{\mathrm{a}}\right)$ and chlorophyll $b\left(\mathrm{Chl}_{\mathrm{b}}\right)$ concentration (mg $\left.\mathrm{g}^{-1}\right)$, and $\mathrm{Chl}_{\mathrm{a} / \mathrm{b}}$ ratio of 16 spring wheat genotypes grown under two sowing times (CS, conventional; LS, late) and irrigation treatments (RF, rainfed; IR, irrigated) during the 2011/2012 (2012) and 2012/2013 (2013) crop growing seasons at Adana, Turkey.

\begin{tabular}{|c|c|c|c|c|c|c|c|c|c|c|}
\hline \multirow[b]{2}{*}{ Values } & \multicolumn{5}{|c|}{2012} & \multicolumn{5}{|c|}{2013} \\
\hline & SPAD & $\mathrm{Chl}_{\mathrm{a}}$ & $\mathbf{C h l}_{\mathbf{b}}$ & $\mathrm{Chl}_{\mathrm{a}+\mathrm{b}}$ & Chl a/b & SPAD & $\mathrm{Chl}_{\mathrm{a}}$ & $\mathbf{C h l}_{\mathbf{b}}$ & $\mathrm{Chl}_{\mathrm{a}+\mathrm{b}}$ & Chl a/b \\
\hline & & & CSRF & & & & & CSRF & & \\
\hline Maximum & 51.6 & 2.53 & 0.75 & 3.28 & 3.70 & 52.0 & 2.36 & 0.67 & 3.01 & 3.95 \\
\hline Minimum & 42.6 & 1.85 & 0.55 & 2.39 & 2.90 & 44.6 & 1.95 & 0.53 & 2.48 & 3.35 \\
\hline Mean & 45.8 & 2.16 & 0.67 & 2.82 & 3.26 & 46.5 & 2.13 & 0.59 & 2.72 & 3.66 \\
\hline $\mathrm{LSD}_{0.05}$ & 4.04 & 0.255 & $\begin{array}{c}0.101 \\
\text { CSIR }\end{array}$ & 0.337 & 0.343 & 3.41 & ns & $\begin{array}{r}\text { ns } \\
\text { CSIR }\end{array}$ & ns & $\mathrm{ns}$ \\
\hline Maximum & 47.7 & 2.20 & 0.69 & 2.85 & 3.90 & 52.2 & 2.25 & 0.68 & 2.93 & 3.75 \\
\hline Minimum & 39.1 & 1.65 & 0.45 & 2.10 & 3.08 & 44.5 & 1.87 & 0.51 & 2.38 & 3.30 \\
\hline Mean & 45.8 & 2.03 & 0.59 & 2.62 & 3.48 & 47.0 & 2.09 & 0.60 & 2.69 & 3.51 \\
\hline $\mathrm{LSD}_{0.05}$ & 2.90 & ns & $\begin{array}{l}0.090 \\
\text { LSRF }\end{array}$ & 0.393 & 0.398 & 2.83 & ns & $\begin{array}{c}\text { ns } \\
\text { LSRF }\end{array}$ & ns & $\mathrm{ns}$ \\
\hline Maximum & 53.9 & 2.54 & 0.85 & 3.39 & 3.80 & 56.2 & 2.32 & 0.81 & 3.06 & 3.30 \\
\hline Minimum & 38.5 & 1.78 & 0.54 & 2.42 & 2.35 & 46.4 & 1.67 & 0.55 & 2.26 & 2.68 \\
\hline Mean & 45.8 & 2.12 & 0.70 & 2.81 & 3.10 & 50.3 & 1.95 & 0.66 & 2.62 & 2.98 \\
\hline $\mathrm{LSD}_{0.05}$ & 2.99 & 0.247 & $\begin{array}{c}0.110 \\
\text { LSIR }\end{array}$ & 0.315 & 0.448 & 3.73 & 0.331 & $\begin{array}{c}0.127 \\
\text { LSIR }\end{array}$ & 0.439 & 0.355 \\
\hline Maximum & 51.8 & 2.66 & 1.04 & 3.63 & 3.65 & 53.8 & 1.97 & 0.62 & 2.59 & 3.38 \\
\hline Minimum & 42.2 & 1.95 & 0.57 & 2.55 & 2.53 & 44.4 & 1.50 & 0.49 & 2.01 & 2.95 \\
\hline Mean & 46.9 & 2.28 & 0.74 & 3.02 & 3.13 & 48.7 & 1.79 & 0.58 & 2.37 & 3.16 \\
\hline $\mathrm{LSD}_{0.05}$ & 3.01 & 0.346 & 0.135 & 0.446 & 0.439 & 4.97 & 0.243 & $\mathrm{~ns}$ & ns & $\mathrm{ns}$ \\
\hline
\end{tabular}

ns, not significant at the 0.05 probability level.

SPAD values measured in this study were comparable to those observed in previous studies of spring wheat grown under irrigated and non-limited nitrogen conditions (Del Blanco et al., 2000; Gutiérrez-Rodríguez et al., 2000; Babar et al., 2006) and were near the upper limit of calibration studies in wheat (Monje and Bugbee, 1992; Castelli et al., 1996; Richardson et al., 2002; Uddling et al., 2007). Despite the narrow range within higher values of SPAD, significant and consistent genotypic differences were found. This futher promised analysis of relationships SPAD with extracted chlorophylls.

\section{Extractable chlorophylls}

Except for occasional cases, such as for both pigments in 2013 CSRF and CSIR, for $\mathrm{Chl}_{\mathrm{a}}$ in 2012 CSIR, and for $\mathrm{Chl}_{\mathrm{b}}$ in 2013 LSIR, genotypic differences for extractable concentration of flag leaf $\mathrm{Chl}_{\mathrm{a}}, \mathrm{Chl}_{\mathrm{b}}$, and $\mathrm{Chl}_{\mathrm{a}+\mathrm{b}}$ were generally significant (Table 1). Differences were not evident for both pigments $\left(\mathrm{Chl}_{\mathrm{a}}, \mathrm{Chl}_{\mathrm{b}}\right.$, and therefore $\mathrm{Chl}_{\mathrm{a}+\mathrm{b}}$ ) in the $2013 \mathrm{CSRF}$ and for $\mathrm{Chl}_{\mathrm{b}}$ in the 2013 LSIR environments.

The highest genotypic range in chlorophyll content was observed in 2012 in the LSIR environment, in which Chl content ranged from 318 to $481 \mathrm{mg} \mathrm{m}^{-2}$ for $\mathrm{Chl}_{\mathrm{a}}$, from 96 to $193 \mathrm{mg} \mathrm{m}^{-2}$ for $\mathrm{Chl}_{\mathrm{b}}$, and from 427 to $674 \mathrm{mg} \mathrm{m}^{-2}$ for $\mathrm{Chl}_{\mathrm{a}+\mathrm{b}}$ (data not shown, but can be seen in Figure 2). Genotypic differences in $\mathrm{Chl}_{\mathrm{a} / \mathrm{b}}$ were not evident in three environmets (CSRF, CSIR and LSIR) in 2013. The extent of significant genotypic differences in the other environments changed in a wide range from 23\% (2013 LSRF) to $62 \%$ (2012 LSRF). Changes shown in Table 1 were largely similar when the two genotypes that exhibit early (Karacadağ-98) and late (Cumakalesi) development were not considered.

One of the most remarkable results in the present study was the trend for declining $\mathrm{Chl}_{\mathrm{a} / \mathrm{b}}$ under $\mathrm{LS}$ warm conditions in both years due to increased $\mathrm{Chl}_{\mathrm{b}}$. The ratio of $\mathrm{Chl}_{\mathrm{a}}$ to $\mathrm{Chl}_{\mathrm{b}}$ is known to change with environmental factors such as light. Lichtenthaler and Wellburn (1983) reported that plants exposed to high irradiance show high $\mathrm{Chl}_{\mathrm{a} / \mathrm{b}}$ ratios, whereas plants growing in environments with reduced irradiance have a lower $\mathrm{Chl}_{\mathrm{a} / \mathrm{b}}$ ratios. The variation in $\mathrm{Chl}_{\mathrm{a} / \mathrm{b}}$ ratio in the current study seem not to be due to reduced radiation, as light intensity above the canopy constantly increases during the spring months, when late-sown crops are grown. The reduction $\mathrm{Chl}_{\mathrm{a} / \mathrm{b}}$ under LS conditions may be caused by increased growing temperatures during the flag leaf expansion. For a precise interpretation, temperature and irradiance measurements at the flag leaf level in the canopy during flag leaf expansion are needed.

\section{Relationship of SPAD greenness with chlorophyll concentration and $C h l_{a / b}$}

The linear, quadratic and exponential (data not shown) relationships among chlorophyll concentration and $\mathrm{Chl}_{\mathrm{a} / \mathrm{b}}$ with SPAD greenness were generally similar. The linear and quadratic regression coefficients of determination $\left(R^{2}\right)$ for flag leaf chlorophyll concentration $\left(\mathrm{Chl}_{\mathrm{a}}, \mathrm{Chl}_{\mathrm{b}}\right.$, and $\mathrm{Chl}_{\mathrm{a}+\mathrm{b}}$ per unit fresh weight) and $\mathrm{Chl}_{\mathrm{a} / \mathrm{b}}$ with SPAD greenness are illustrated in Table 2. The degree of quadratic fit was improved only in two environments, namely in $2012 \mathrm{LSRF}$ and $2013 \mathrm{CSRF}$ for $\mathrm{Chl}_{\mathrm{a}}$ and $\mathrm{Chl}_{\mathrm{b}}$, respectively. 
Table 2. Relationships of flag leaf extracted chlorophyll (Chl) concentration and $\mathrm{Chl}_{\mathrm{a} / \mathrm{b}}$ ratio with SPAD greenness for 16 spring wheat genotypes grown under two sowing times (CS,conventional; LS, late) and irrigation treatments (RF, rainfed; IR, irrigated) during the 2011/2012 (2012) and 2012/2013 (2013) crop growing seasons at Adana, Turkey.

\begin{tabular}{|c|c|c|c|c|c|c|c|c|c|}
\hline \multirow[b]{2}{*}{ Regression } & \multicolumn{5}{|c|}{2012} & \multicolumn{4}{|c|}{2013} \\
\hline & $\mathrm{Chl}_{\mathrm{a}}$ & $\mathrm{Chl}_{\mathrm{b}}$ & $\mathrm{Chl}_{\mathbf{a}+\mathrm{b}}$ & & $\mathbf{C h l}_{\mathrm{a} / \mathrm{b}}$ & $\mathrm{Chl}_{\mathrm{a}} \mathrm{Ch}$ & $\mathbf{C h l}_{\mathbf{a}+\mathbf{b}}$ & & $\mathrm{Chl}_{\mathrm{a} / \mathrm{b}}$ \\
\hline & & CSRF & & & & CSRF & & & \\
\hline Linear & $\mathrm{R}^{2}$ & 0.17 & 0.15 & 0.18 & 0.02 & 0.03 & $0.25 *$ & 0.07 & 0.19 \\
\hline Quadratic & $\mathrm{R}^{2}$ & $\begin{array}{l}0.17 \\
\text { CSIR }\end{array}$ & 0.15 & 0.18 & 0.22 & $\begin{array}{l}0.04 \\
\text { CSIR }\end{array}$ & $0.49 *$ & 0.14 & 0.20 \\
\hline Linear & $\mathrm{R}^{2}$ & 0.10 & $0.31 *$ & 0.18 & $0.38 *$ & 0.11 & 0.17 & 0.13 & 0.08 \\
\hline Quadratic & $\mathrm{R}^{2}$ & $\begin{array}{l}0.18 \\
\text { LSRF }\end{array}$ & $0.35(\mathrm{p}: 0.06)$ & 0.22 & $0.47 *$ & $\begin{array}{l}0.11 \\
\text { LSRF }\end{array}$ & 0.17 & 0.13 & 0.08 \\
\hline $\begin{array}{l}\text { Linear } \\
\text { Quadratic }\end{array}$ & $\begin{array}{l}\mathrm{R}^{2} \\
\mathrm{R}^{2}\end{array}$ & $\begin{array}{l}0.22 \\
0.41 * \\
\text { LSIR }\end{array}$ & $\begin{array}{l}0.04 \\
0.07\end{array}$ & $\begin{array}{l}0.18 \\
0.25\end{array}$ & $\begin{array}{l}0.04 \\
0.15\end{array}$ & $\begin{array}{l}0.40^{* *} \\
0.41 * \\
\text { LSIR }\end{array}$ & $\begin{array}{l}0.31 * \\
0.37 \text { (p:0.052) }\end{array}$ & $\begin{array}{l}0.39 * \\
0.39 *\end{array}$ & $\begin{array}{l}0.00 \\
0.00\end{array}$ \\
\hline $\begin{array}{l}\text { Linear } \\
\text { Quadratic }\end{array}$ & $\begin{array}{l}\mathrm{R}^{2} \\
\mathrm{R}^{2}\end{array}$ & $\begin{array}{l}0.20 \\
0.32\end{array}$ & $\begin{array}{l}0.14 \\
0.14\end{array}$ & $\begin{array}{l}0.20 \\
0.21\end{array}$ & $\begin{array}{l}0.02 \\
0.02\end{array}$ & $\begin{array}{l}0.49 * * \\
0.51 * *\end{array}$ & $\begin{array}{l}0.30 * \\
0.32\end{array}$ & $\begin{array}{l}0.47 * * \\
0.49 *\end{array}$ & $\begin{array}{l}0.00 \\
0.02\end{array}$ \\
\hline
\end{tabular}

,** significance at 0.05 and 0.01 probability levels, respectively.

Linear relationships between SPAD greenness and chlorophyll concentration $\left(\mathrm{Chl}_{\mathrm{a}}, \mathrm{Chl}_{\mathrm{b}}\right.$, and $\mathrm{Chl}_{\mathrm{a}+\mathrm{b}}$ per unit fresh weight) were consistently positive (Table 2). However, the relationships were significant only in the $2013 \mathrm{LS}, \mathrm{RF}$ and IR environments for $\mathrm{Chl}_{\mathrm{a}}, \mathrm{Chl}_{\mathrm{b}}$, and $\mathrm{Chl}_{\mathrm{a}+\mathrm{b}}$ and in the 2012 CSIR and 2013 CSRF environments for $\mathrm{Chl}_{\mathrm{b}}$. Except a weak negative correlation under CSIR in the first year $\left(r=-0.38^{*}\right)$, relationships between SPAD greenness and $\mathrm{Chl}_{\mathrm{a} / \mathrm{b}}$ were not significant.

Although many studies have reported a nonlinear (curvilinear) relationships between extracted chlorophylls and SPAD greenness (Monje and Bugbee, 1992; Markwell et al., 1995; Castelli et al., 1996; Bindi et al., 2002; Richardson et al., 2002; Jifon et al., 2005; Uddling et al., 2007), a linear model was also used in the present study, as chlorophyll amounts recorded were quite high and ranged within very narrow limits.

\section{Relationship of SPAD greenness with chlorophyll content}

Only linear relationships were considered, as the relationship of flag leaf SPAD greenness and extractable chlorophyll content estimated by linear and quadratic relationships did not show large differences. Exponential relationships (data not shown) also did not improve prediction of chlorophyll content.

The equations $\left(\mathrm{Chl}_{\mathrm{a}}=8.6093 x-29.496, \mathrm{Chl}_{\mathrm{b}}=\right.$ $\left.3.0695 x-28.085, \mathrm{Chl}_{\mathrm{a}+\mathrm{b}}=11.673 x-57.265\right)$ quantifying the linear relationship between SPAD greennes and chlorophyll content for the 16 genotypes averaged over the eight environments demonstrated a moderate association with $R^{2}$ values of $0.65 * * *, 0.550 * *$ and $0.64 * * *$ for $\mathrm{Chl}_{\mathrm{a}}, \mathrm{Chl}_{\mathrm{b}}$, and $\mathrm{Chl}_{\mathrm{a}+\mathrm{b}}$, respectively. However, the equations were not always valid if the individual environments were considered seperately, as shown in Figure 1 and Figure 2 for CS and LS, respectively. The relationship of SPAD greenness with $\mathrm{Chl}_{\mathrm{a},} \mathrm{Chl}_{\mathrm{b}}$, and $\mathrm{Chl}_{\mathrm{a}+\mathrm{b}}$ was positive; hence, in all environments increased flag leaf greenness was associated with increased chlorophyll content. Nevertheless, the distribution of the data around the regression line $\left(R^{2}\right)$ varied with the environment.

A generally weak or moderate relationship was observed between total extractable chlorophyll content and SPAD greenness $\left(R^{2}\right.$ values ranged from $0.24[p=$ 0.054] in 2013 CSRF to $0.64 * * *$ in 2013 LSRF) (Figure 1 and Figure 2). Most relationship between flag leaf $\mathrm{Chl}_{\mathrm{a}+\mathrm{b}}$ and SPAD greenness were significant but of limited predictive value, especially under CS (Figure 1). However, the association was improved under LS (Figure 2).

The relationships between $\mathrm{Chl}_{\mathrm{a}}$ content and SPAD greenness were similar to those between total extractable chlorophyll content and SPAD greenness (Figure 1 and Figure 2). The associations were to a certain degree stronger, with highest $R^{2}$ values of $0.71 * * *$ in 2013 LSRF and $0.61 * * *$ in 2012 LSIR. The relationship between SPAD greenness and $\mathrm{Chl}_{\mathrm{a}}$ was insignificant in 2013 CSRF, consistent with the significance of the relationship between SPAD greenness and total chlorophyll content.

The association of SPAD greenness with $\mathrm{Chl}_{\mathrm{b}}$ content was weaker than those with total chlorophyll and $\mathrm{Chl}_{\mathrm{a}}$ as also reported by Richardson et al. (2002) for paper birch leaves. The strongest relationship was observed in 2012 CSIR $\left(R^{2}=0.46^{* *}\right)$ followed by $2013 \operatorname{CSIR}\left(R^{2}=\right.$ 0.43**) (Campbell et al., 1990; Monje and Bugbee, 1992; Jifon et al., 2005; Neufeld et al., 2006). The associations in CSRF and LSRF in 2012 could not be proven. The coefficients of determination in the remaining environments ranged between $0.33^{*}$ and $0.40^{* *}$.

The association of SPAD greenness with chlorophyll content (when chlorophyll was expressed on a leaf area basis) observed in this study was stronger than the association with chlorophyll concentration (when chlorophyll was expressed on a leaf fresh weight basis), as has been reported previously (Marquard and Tipton, 1987; Uddling et al., 2007). 


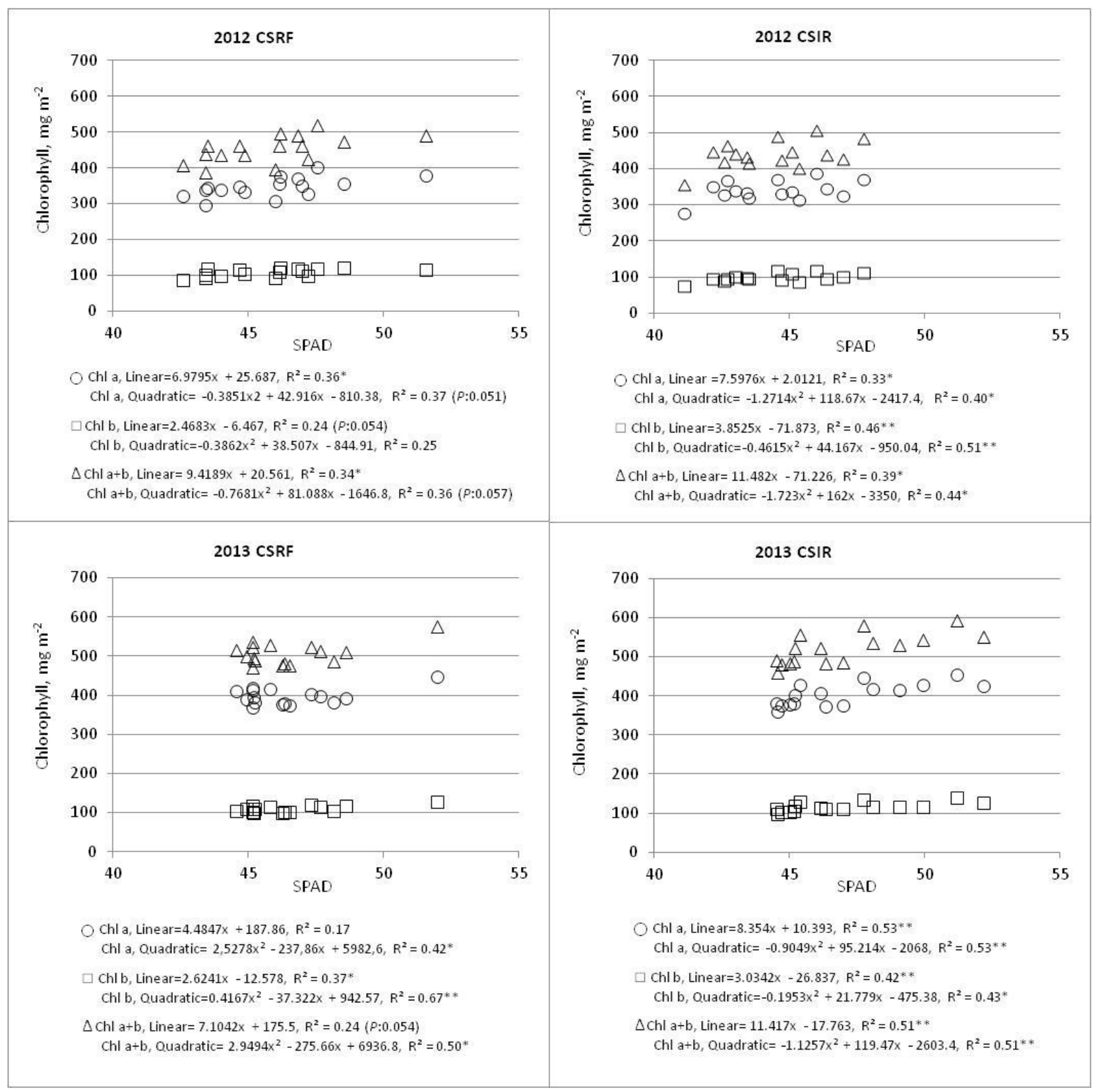

Figure 1. Relationship between flag leaf extracted chlorophyll (Chl) content and SPAD greenness for 16 spring wheat genotypes grown under a conventional sowing (CS) time and two irrigation treatments (RF, rainfed; IR, irrigated) during the 2011/2012 (2012) and 2012/2013 (2013) crop growing seasons at Adana, Turkey. *, ** significance at 0.05 and 0.01 probability levels, respectively. 


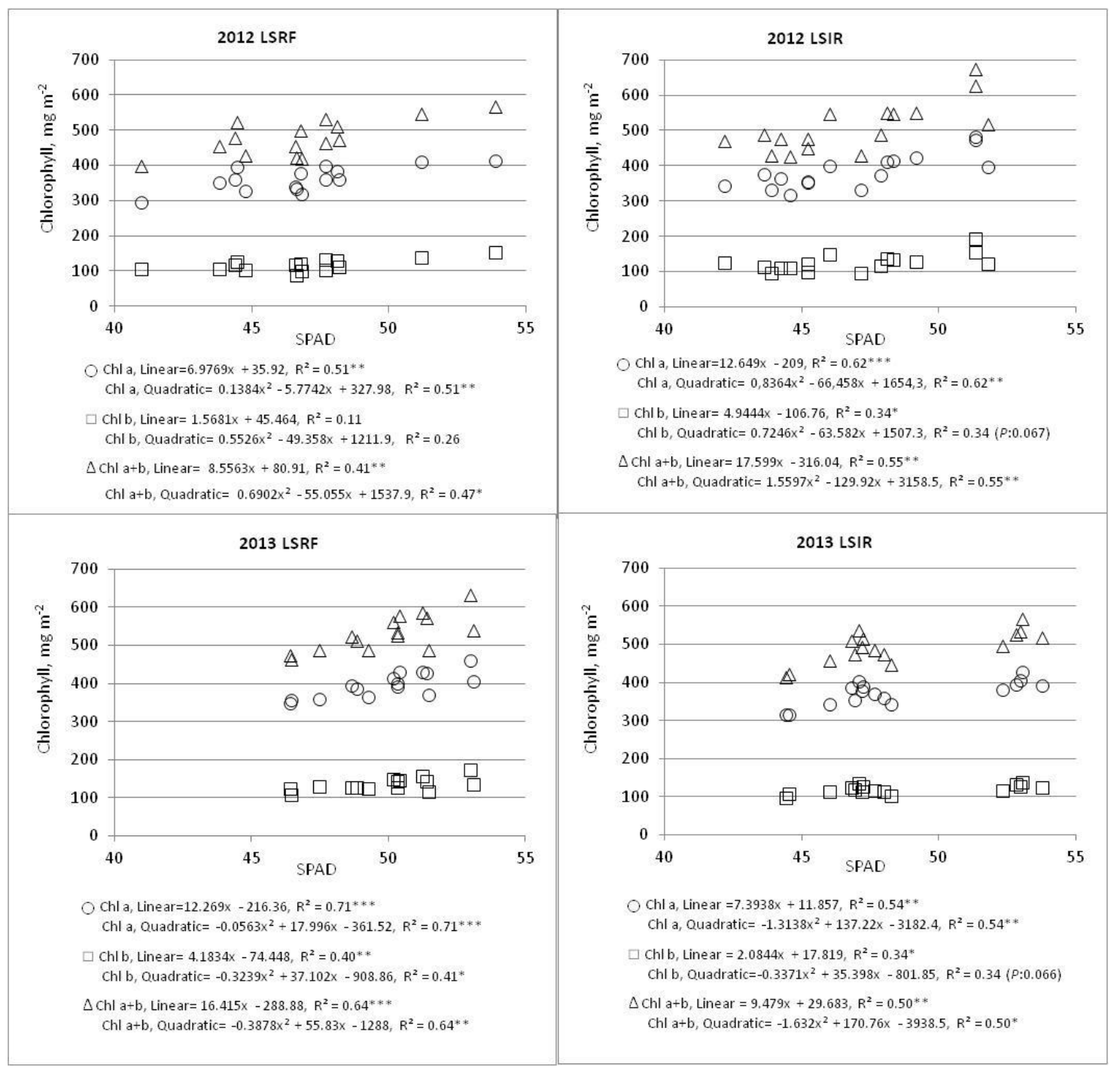

Figure 2. Relationship between flag leaf extracted chlorophyll (Chl) content and SPAD greenness for 16 spring wheat genotypes grown under a late sowing (LS) time and two irrigation treatments (RF, rainfed; IR, irrigated) during the 2011/2012 (2012) and $2012 / 2013$ (2013) crop growing seasons at Adana, Turkey. ***, *** significance at $0.05,0.01$ and 0.001 probability levels, respectively.

The results of this study further suggest that the usefulness of SPAD readings in typical Mediterranean wheat growing conditions is questionable and, for prediction purposes, growing conditions are an important consideration and the date (growing conditions) cannot be pooled. Complex optical properties due to factors other than the chlorophyll amount in the leaf, which change with growing environment, seem problematic for application of SPAD greenness.

\section{CONCLUSIONS}

Genotypic differences in flag leaf SPAD greenness and extractable chlorophylls among spring wheat genotypes with similar development provided the opportunity to assess the accuracy and precision of SPAD readings to estimate genotypic variation in flag leaf chlorophyll amounts independent of phenology (leaf age).

The ability of the SPAD-502 meter to estimate genotypic differences in chlorophyll content per unit flag

leaf area was satisfactory as long as the leaves developed under warm (and irrigated) conditions. It might be due to the fact that cell under warm condition perform well having more chlorophyll contents of leaf morphology. Secondly the genetic variation could be the main reason of high chlorophyll contents of some varieties performing well under Mediterranean conditions. However, the SPAD meter was less reliable for estimation of genotypic variation in leaf chlorophyll under the typical cooler wheat-growing conditions of the Mediterranean, where genetic variability, especially in $\mathrm{Chl}_{\mathrm{b}}$, was not expressed adequately. Applicability of the SPAD-502 meter also might be restricted when the objective is to assess the capacity of the photosynthetic antenna system, as SPAD greenness was generally a better indicator of $\mathrm{Chl}_{\mathrm{a}}$ and $\mathrm{Chl}_{\mathrm{a}+\mathrm{b}}$ than $\mathrm{Chl}_{\mathrm{b}}$. This is the one of the main drawback of SPAD meter in determining the photosynthetic antenna system of plants. Therefore instrument must be updated to determine the both chlorophyl contents as well as light harvesting capacity of leaf. Further research is also 
indispensible at cellular level to understand the efficiency of SPAD for putting a theoratical conclusions. In spite of these limitations, chlorophyll meters are valuable instruments if they are properly calibrated with extractable chlorophyll measurements for a given set of growing conditions.

\section{ACKNOWLEDGMENTS}

This research was supported by the Scientific and Technological Research Council of Turkey (TUBITAK) Project no. 1100345 .

\section{LITERATURE CITED}

Araus, J.L., G.A. Slafer, C. Royo, M.D. Serret. 2008. Breeding for Yield Potential and Stress Adaptation in Cereals. Critical Reviews in Plant Sci. 27: 377-412.

Arnon, D.I.. 1949. Copper enzymes in isolated chloroplasts; Polyphenoloxidases in Beta vulgaris. Plant Physiol. 24: 115.

Babar, M.A, M.P. Reynolds, M. Van Ginkel, A.R. Klatt, W.R. Raun, M.L. Stone. 2006. Spectral Reflectance to Estimate Genetic Variation for In-Season Biomass, Leaf Chlorophyll, and Canopy Temperature in Wheat. Crop Sci. 46: 10461057.

Bindi, M., A. Hacour, K. Vandermeiren, J. Craigon, K. Ojanpera, G. Sellden, P. Hogy, J. Finnan, L. Fibbi. 2002. Chlorophyll concentration of potatoes grown under elevated carbon dioxide and/or ozone concentrations. European Journal of Agron. 17: 319 -335.

Campbell, R.J., K.N. Mobley, R.P. Marini, D.G. Pfeiffer. 1990. Growing conditions alter the relationship between SPAD501 values and apple leaf chlorophyll. Hortsci. 25: 330-331.

Castelli, F., R. Contillo, F. Miceli. 1996. Non-destructive Determination of Leaf Chlorophyll Content in Four Crop Species. Journal of Agronomy and Crop Sci. 177: 275-283.

Del Blanco, I.A., S. Rajaram, W.E. Kronstad, M.P. Reynolds. 2000. Physiological performance of synthetic hexaploid wheat-derived populations. Crop Sci. 40: 1257-1263.

Evans, J.R.. 1983. Nitrogen and photosynthesis in the flag leaf of wheat (Triticum aestivum L.). Plant Physiol. 72: 297 - 302.

Fritschi, F.B., J.D. Ray. 2007. Soybean leaf nitrogen, chlorophyll content, and chlorophyll $\mathrm{a} / \mathrm{b}$ ratio. Photosynthetica 45 (1): 92-98.

Gutiérrez-Rodríguez, M., M.P. Reynolds, A. Larqué-Saavedra. 2000. Photosynthesis of wheat in a warm, irrigated environment II. Traits associated with genetic gains in yield. Field Crops Research 66: 51-62.

Hoel, B.O., K.A. Solhaug. 1998. Company Effect of Irradiance on Chlorophyll Estimation with The Minolta SPAD-502 Leaf Chlorophyll Meter. Annals of Bot. 82: 389-392.

Jifon, J.L., J.P. Syvertsen, E. Whaley. 2005. Growth environment and leaf anatomy affect non-destructive estimates of chlorophyll and nitrogen in Citrus sp. leaves. Journal of American Society of Horticultural Sci., 130: 152 158.

Lichtenthaler, H.K., A.R.Wellburn. 1983. Determinations of total carotenoids and chlorophylls a and b of leaf extracts in different solvents. Biochemical Society Transactions, 11: 591-592.

Lopes, M.S., M.P. Reynolds. 2012. Stay-green in spring wheat can be determined by spectral reflectance measurements (normalized difference vegetation index) independently from phenology. Journal of Experimental Bot. 63: 3789-3798.

Markwell, J., J.C. Osterman, J.L. Mitchell. 1995. Calibration of the Minolta SPAD-502 leaf chlorophyll meter. Photosynthesis Res. 46: 467-472.
Marquard, R.D., J.L. Tipton. 1987. Relationship between extractable chlorophyll and an in situ method to estimate leaf greenness. HortSci. 22: 1327

Martínez, D.E., J.J. Guiamet. 2004. Distortion of the SPAD 502 chlorophyll meter readings by changes in irradiance and leaf water status. Agronomie, 24, 41-46.

Monje, O.A., Bugbee B.. 1992. Inherent limitations of nondestructive chlorophyll meters: A comparison of two types of meters. HortSci. 27: 69-71.

Neufeld, H.S., A.H. Chappelka, G.L. Somers, K.O. Burkey, A.W. Davison, P.L. Finkelstein. 2006. Visible foliar injury caused by ozone alters the relationship between SPAD meter readings and chlorophyll concentrations in cutleaf coneflower. Photosynthesis Res. 87, 281-286.

Palta, J.P.. 1990. Leaf chlorophyll content. Remote Sensing Reviews, 5: 207-213.

Parry, M.A.J., M. Reynolds, M.E. Salvucci, C. Raines, P.J. Andralojc, X-G. Zhu, G.D. Price, A.G. Condon, R. Furbank. 2011. Raising Yield Potential of Wheat: (II) Increasing photosynthetic capacity and efficiency. Journal of Experimental Bot. 62: 453-467.

Porra, R.J., W.A. Thompson, P.E. Kreidemann. 1989. Determination of accurate extinctions coefficients and simultaneous equations for assaying chlorophylls $a$ and $b$ extracted with four different solvents: verification of the concentration of chlorophyll standards by atomic absorption spectroscopy. Biochimica et Biophysica Acta (BBA) Bioenergetics, 975: 384-394.

Reynolds, M.P., M. Balota, M.I.B. Delgado, I. Amani, R.A.Fischer. 1994. Physiological and morphological traits associated with spring wheat yield under hot, dry irrigated conditions. Australian Journal of Plant Physiol. 21: 717-730.

Reynolds, M.P., M.I.B. Delgado, M. Gutierrez-Rodriguez, A. Larque-Saavedra. 2000. Photosynthesis of wheat in a warm, irrigated environment. I. Genetic diversity and crop productivity. Field Crops Res. 66: 37-50.

Richardson, A.D., S.P. Duigan, G.P. Berlyn. 2002. An evaluation of noninvasive methods to estimate foliar chlorophyll content. New Phytologist, 153: 185-194.

Ruiz-Espinoza, F. H., B. Murillo-Amador, J. L. GarcíaHernández, L. Fenech-Larios, E. O. Rueda-Puente, E. TroyoDiéguez , C. Kaya, A. Beltrán-Morales. 2010. Field evaluation of the relationship between chlorophyll content in basil leaves and a portable chlorophyll meter (SPAD-502) readings. Journal of Plant Nutrition 33:423 - 438.

SPSS, 1999. SYSTAT User's Guide: Statistics. Version 9.0. SPSS, Inc., Chicago, IL

Uddling, J., J. Gelang-Alfredsson, K. Piikki, H. Pleijel. 2007. Evaluating the relationship between leaf chlorophyll concentration and SPAD-502 chlorophyll meter readings. Photosynthesis Res. 91: 37-46.

Xiao, Y.G., Z.G. Qian, K. Wu, J.J. Liu, X.C. Xia, W.Q. Ji, Z.H. He. 2012. Genetic gains in grain yield and physiological traits of winter wheat in Shandong Province, China, from 1969 to 2006. Crop Sci. 52: 44-56.

Yamamoto, A., T. Nakamura, J.J. Adu-Gyamfi, M. Saigusa. 2002. relationship between chlorophyll content in leaves of sorghum and pigeonpea determined by extraction method and by chlorophyll meter (SPAD-502). Journal of Plant Nutrition 25(10): 2295 - 2301 .

Zadoks, J.C., T.T. Chang, C.F. Konzak. 1974. A decimal code for the growth stages of cereals. Weed Res. 14: 415-421.

Zhang, C.J., G.X. Chen, X.X. Gao, C.J. Chu. 2006. Photosynthetic decline in flag leaves of two field-grown spring wheat cultivars with different senescence properties. South African Journal of Bot. 72: 15 -23. 